\title{
A role of active brown adipose tissue in cancer cachexia?
}

\author{
Emiel Beijer, ${ }^{1}$ Janna Schoenmakers, ${ }^{2}$ Guy Vijgen, 3,5,6 Fons Kessels, ${ }^{7,8}$ \\ Anne-Marie Dingemans, ${ }^{2,4}$ Patrick Schrauwen, 5,6 Miel Wouters, 2,6 \\ Wouter van Marken Lichtenbelt, ${ }^{5,6}$ Jaap Teule, ${ }^{1}$ Boudewijn Brans ${ }^{1,4}$ \\ Departments of ${ }^{1}$ Nuclear Medicine, ${ }^{2}$ Respiratory ${ }^{3}$ Medicine and Surgery, ${ }^{4}$ GROW School for Onco- \\ logy and Developmental Biology, ${ }^{5}$ Department of Human Biology, ${ }^{6}$ NUTRIM School for Nutrition, \\ Toxicology and Metabolism, ${ }^{7}$ Department of Clinical Epidemiology and Medical Technology \\ Assessment (MTA), ${ }^{8}$ CAPHRI School for Public Health and Primary Care, Maastricht University and \\ Maastricht University Medical Centre, The Netherlands
}

\begin{abstract}
Until a few years ago, adult humans were not thought to have brown adipose tissue (BAT). Now, this is a rapidly evolving field of research with perspectives in metabolic syndromes such as obesity and new therapies targeting its bio-energetic pathways. White, brown and socalled brite adipose fat seem to be able to trans-differentiate into each other, emphasizing the dynamic nature of fat tissue for metabolism. Human and animal data in cancer cachexia to date provide some evidence for BAT activation, but its quantitative impact on energy expenditure and weight loss is controversial. Prospective clinical studies can address the potential role of BAT in cancer cachexia using ${ }^{18} \mathrm{~F}$-fluorodeoxyglucose positron emission tomography-computed tomography scanning, with careful consideration of co-factors such as diet, exposure to the cold, physical activity and body mass index, that all seem to act on BAT recruitment and activity.
\end{abstract}

\footnotetext{
Correspondence: Boudewijn Brans, Maastricht University Medical Center, Postbox 5800, 6202 AZ Maastricht, The Netherlands.

Tel. +31.43 .3874746 - Fax: +31.43 .3876746 .

E-mail: b.brans@mumc.nl

Key words: cancer, cachexia, brown adipose tissue, brown fat, energy expenditure, thermogenesis, UCP-1, ${ }^{18}$ F-FDG PET-CT.

Contributions: EB, JS, these authors contributed equally to this manuscript.

Conflict of interests: Emiel Beijer and Janna Schoenmakers are recipients of a grant by The Weijerhorst Foundation.

Received for publication: 3 February 2012.

Revision received: 4 June 2012.

Accepted for publication: 7 June 2012

This work is licensed under a Creative Commons Attribution NonCommercial 3.0 License (CC BY-NC 3.0).

CC Copyright E. Beijer et al., 2012

Licensee PAGEPress, Italy

Oncology Reviews 2012; 6:e11

doi:10.4081/oncol.2012.e11
}

\section{Introduction}

\section{Cancer cachexia and hypermetabolism}

Cancer cachexia is recognized as a distinct clinical disorder with a negative impact on quality of life, therapeutic success and prognosis. The recently redefined criteria for cachexia are weight loss of more than $5 \%$ over the previous six months or weight loss of more than $2 \%$ in individuals who already show a state of depletion according to decreased bodyweight (Body Mass Index or BMI $<20 \mathrm{~kg} / \mathrm{m}^{2}$ ) or skeletal muscle index (sarcopenia). ${ }^{1}$ Cancer cachexia frequency varies with the type of malignancy, occurring more frequently in patients with lung and upper gastrointestinal cancer and less often in patients with breast cancer or lower gastrointestinal cancer. ${ }^{2}$

Current evidence on the pathogenesis of the cachexia syndrome points to a central disturbance of the hypothalamic pathways controlling energy homeostasis, resulting in reduced energy intake and anorexia, increased energy expenditure, and loss of body tissue, i.e. muscle proteolysis and lipolysis. ${ }^{3}$ Resting energy expenditure or metabolic rate (RMR) accounts for the major proportion of up to $70 \%$ of total energy expenditure in sedentary subjects. ${ }^{4}$ Hypermetabolism has been found to be elevated in some but not all cancer patients, ${ }^{5}$ for example, in approximately $50 \%$ of a mixed cancer population ${ }^{6,7}$ and in up to $74 \%$ of primary lung cancer patients. ${ }^{8}$ Cancer patients who lose weight have higher RMR than patients with a constant weight. ${ }^{6}$

Several pathophysiological mechanisms for an inappropriately elevated RMR in cancer cachexia have been proposed, i.e. abnormalities in the carbohydrate, fat or protein metabolism, systemic inflammation, hyperadrenergic activity and an increased liver mass., ${ }^{4,6,9-11}$ In addition, it was suggested as early as 1981 that activation of brown adipose tissue (BAT) results in a hypermetabolic state and is partially responsible for weight loss in cancer patients ${ }^{12}$ but this was in contrast to the widespread view that BAT is only present in newborns and that it disappeared in human adulthood. The human and animal studies discussed here were retrieved from a systematic literature search of relevant medical databases (Medline, Embase, Cochrane Library) using the key words brown adipose tissue, cancer and cachexia (Supplementary Figure S1).

\section{Brown adipose tissue activity}

In 2002, Hany et al. ${ }^{13}$ suggested the existence of functional BAT in adults with the introduction of combined positron emission tomography-computed tomography (PET-CT) scans, showing increased metabolism and glucose uptake with ${ }^{18} \mathrm{~F}$-fluoro-deoxyglucose $\left({ }^{18} \mathrm{~F}-\mathrm{FDG}\right)$ in 
areas that were unmistakably fat tissue on the basis of Hounsfield units on the CT. ${ }^{13}$ Nedergaard et al. ${ }^{14}$ discussed the perspectives presented by this observation to study BAT function in humans. So far, several independent studies ${ }^{15-18}$ have confirmed the existence of functional BAT in adult humans, using cold-induced BAT activation, ${ }^{18} \mathrm{~F}-\mathrm{FDG}$ PET-CT scanning and biopsy verification.

The primary function of BAT is facultative thermogenesis, i.e. regulated heat production in response to a decrease in core body temperature with environmental cold exposure. For this, BAT cells are characterized by an abundance of mitochondria, in contrast to white adipose tissue (WAT). The thermogenic effect of BAT is due to the exclusive presence of uncoupling protein 1 (UCP1) which mediates proton leakage across the inner mitochondrial membrane, thus decreasing the level of coupling of respiration to ADP phosphorylation. In this way, heat is produced instead of energy stored as ATP (Figure 1). Environmental cold exposure causes BAT cells to increase their number of mitochondria and UCP1 synthesis through sympathetic adrenergic stimulation. Human studies have demonstrated that ${ }^{18} \mathrm{FDG}$ uptake in BAT is directly proportional to the expression of UCP1 $16,18,19$ and the cold-induced rise in energy expenditure. ${ }^{20}$ Therefore, ${ }^{18} \mathrm{FDG}$ activity on PET-CT scan can be used as a surrogate marker as a non-invasive technique to measure BAT activity in vivo (Figure 2).

Another relevant recent discovery has been the identification of socalled brite (or beige or systemic) adipose cells which reside among the much larger area of WAT tissue in both subcutaneous and trunk (visceral) compartments. These were so named because they have the same origin (from a myogenic factor 5 (myf5)-negative mesodermal stem cell) as WAT cells, but different from the myf5-positive adipomyoblast that gives rise to myocytes and the classical brown adipocytes that occupy the deposits, as seen in Figure $2 .{ }^{21}$ Although genotypically different, the thermogenic phenotype of brite and brown cells has been shown to be similar. ${ }^{22}$ Importantly, differentiated brite and white fat cells have the capacity for reversible trans-differentiation into each other, ${ }^{23}$ a process that is also closely related to the activity of the sympathetic system. This system provides a large metabolic reservoir for recruitable combustion (WAT $\rightarrow$ BAT conversion) or storage (BAT $\rightarrow$ WAT conversion) of energy and lipid tissue metabolites.

Several review publications over the last few years have addressed the develpments in this growing field, hypothesizing on the possible importance of BAT function on substrate and energy homeostasis of the body. Many of these have focussed on obesity, with the prospect of therapeutic WAT $\rightarrow$ BAT conversion, thermogenic activity, weight loss and conversion of metabolic abnormalities. ${ }^{24-26}$ Along these chain of events,

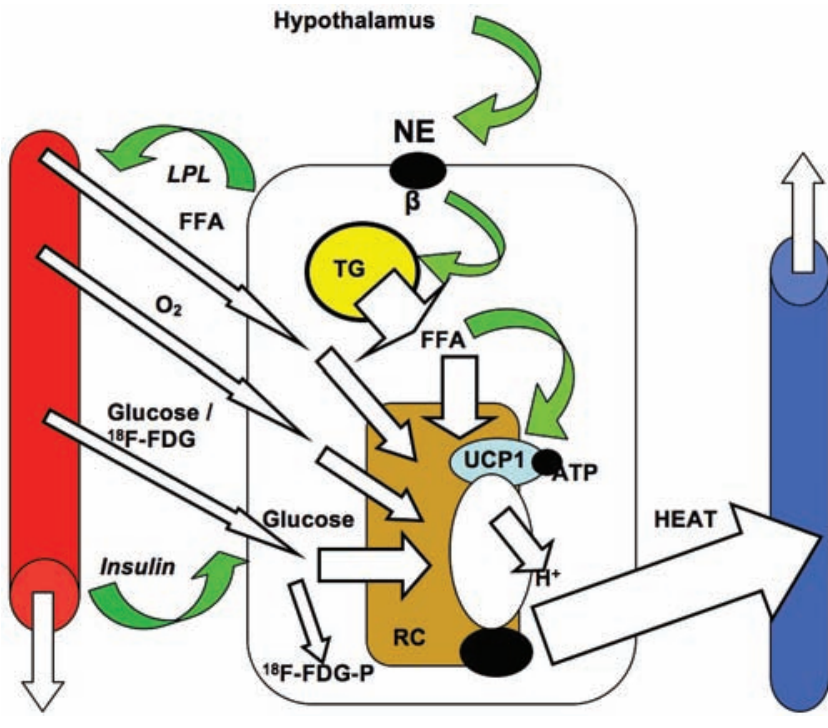

Figure 1. Schematic representation of the thermogenesis in brown adipose tissue (BAT) cells. Information such as body temperature and feeding status is integrated in the hypothalamus from where branches of the sympathetic nervous system innervate BAT through norepinefrine (NE) transmission and predominantly $\beta 3$ beta-adrenergic agonism. The intracellular signal releases triglicerides from the lipid droplet (yellow) in the cytosol, as well as synthesis and release of lipoprotein lipase (LPL) and stimulation of glucose [or its equivalent ${ }^{18} \mathrm{~F}$-fluoro-deoxyglucose $\left({ }^{18} \mathrm{~F}\right.$ FDG)]. Released free fatty acid (FFA) activates uncoupling protein 1 (UCP1) by overcoming the chronic inhibition caused by cytosolic nucleotides such as ATP (or its experimental equivalent guanosine diphosphate). FFA, glucose and oxygen are taken up from the arterial vessels (red) and directed to the mitochondria (brown) for combustion. Insulin stimulates uptake of glucose (and ${ }^{18}$ F-FDG) through the enhanced expression of glucose transporter GLUT-4 in the cell membrane, in addition to increasing LPL expression. ${ }^{18} \mathrm{~F}$-FDG is phosphorylated inside the cytosol and trapped from further metabolization. UCP1, by acting as an equivalent of an $\mathrm{H}^{+}$ transporter, allows extrusion of $\mathrm{H}^{+}$and mitochondrial combustion of substrates in the respiratory chain, uncoupled from ATP production. Instead, heat is produced and dissipated to venous vessels (blue) for further transport to the body.

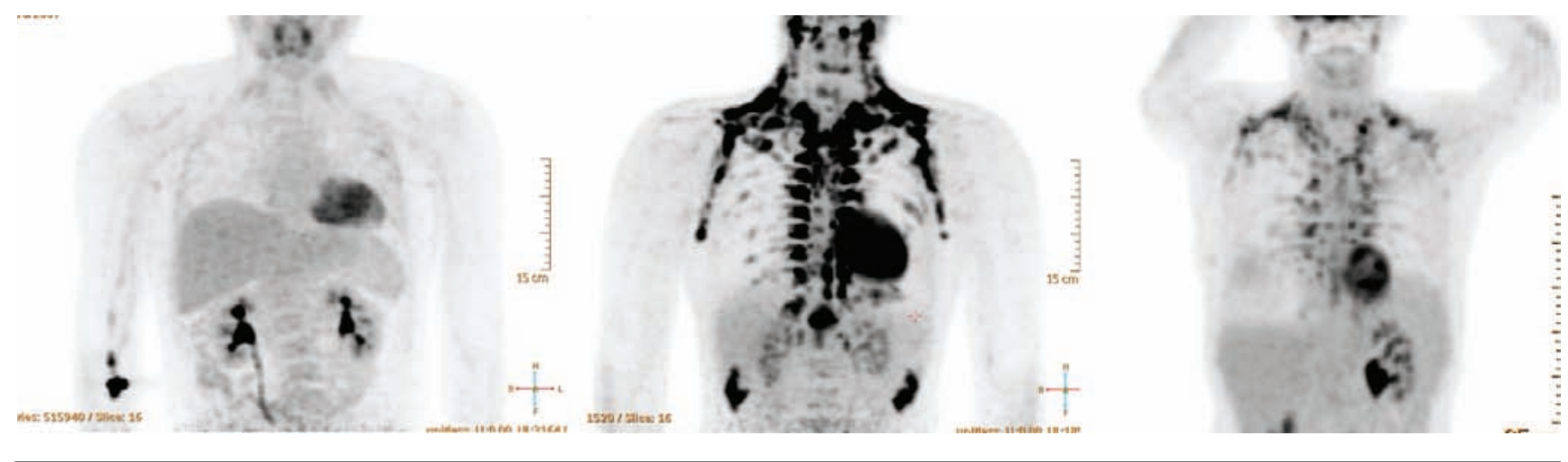

Figure 2. ${ }^{18}$ F-fluoro-deoxyglucose positron emission tomography (PET) scans in normal volunteers, showing no brown adipose tissue (BAT) activity (left), multiple active deposits after cold exposure $\left(16^{\circ} \mathrm{C}\right.$, center) and an example of BAT visualization on a routine PET scan in a patient with rectal cancer (right). Cervical, supraclavicular, axillary, mediastinal, paravertebral and perirenal deposits can be seen. 
the possibility that cancer cachexia is partly mediated by BAT has also re-emerged. New research in this field is facilitated by the availability of PET-CT scans in cancer centers.

\section{Animal studies on cancer cachexia and brown adipose tissue function}

Table 1 shows previous studies that examined the effects of subcutaneous tumor xenograft models on BAT activity in rodents. ${ }^{12,27-33}$ In the early study of Brooks et al., ${ }^{12}$ which was later confirmed by Roe and co-workers, ${ }^{33}$ resting oxygen consumption $\left(\mathrm{VO}_{2}\right)$ as well as core body temperature showed significantly higher values in cachectic tumorbearing mice as compared to pair-fed, non-tumor bearing controls, and these coincided with sympathetic activation of BAT, as judged by mitochondrial guanosine diphosphate (GDP) binding. These results seem to indicate the presence of a state of excessive energy expenditure and thermogenic activity of BAT in cancer cachexia, but they do not establish the corresponding degree of changes in BAT activity, energy expenditure and weight loss. On the other hand, in a study by Oudart, ${ }^{31}$ significant differences were found between tumor-bearing animals and pair-fed controls with regard to BAT mitochondrial COX activity and GDP binding, but not with regard to UCP. Indeed, UCP1 protein levels in BAT tissue can be regarded as the most specific parameter of BAT thermogenic function. ${ }^{34}$ These authors, therefore, suggested that BAT activity, as induced in tumor-bearing animals, is almost exclusively functional and that full fledged BAT tissue development or recruitment is unlikely in cancer cachexia. However, in this study there was no significant difference in final carcass mass between tumor-bearing animals and pair-fed control animals, so there seemed to be a lesser extent of cachexia. Other studies (Table 1) have focussed on the determination of BAT constituents but lack correlation to changes in body temperature and energy expenditure, while different parameters were used to measure BAT activity. For example, lipo-protein lipase (LPL) activity which is synthesized and released from the BAT cells in response to adrenergic stimulation to provide for combustable fatty acids is also strongly confounded by external factors such as insulin levels. These data demonstrate the importance of methodology to the results in these metabolic studies.
The most recent studies have focussed on the effects of several tumor mediators on BAT activity (Table 2) ${ }^{35-41}$ A recent systematic review found circulating levels of tumor necrosis factor-alpha (TNF $\alpha$ ) to be elevated, unchanged or undetectable in cancer patients with cachexia, and no association between systemic serum levels of TNFo and weight loss was found, with the exception of one study in advanced breast cancer. ${ }^{5}$ Emphasizing the importance of a central nervous signalling pathway by TNF- $\alpha$, Arruda et al. ${ }^{35}$ demonstrated a moderate but significant body weight loss and BAT stimulation by intra-cerebro-ventricular administration of TNF- $\alpha$. Importantly, BAT activity as well as coinciding body mass loss, body hyperthermia and inhibition of food intake could be attenuated by prior BAT denervation or administration of a $\beta$-3 antagonist (SR59230A), suggesting a causal link between BAT hyperactivity and cachexia hypermetabolism, as well as therapeutic activity of a $\beta-3$ adrenoceptor antagonist.

Another tumor mediator that has been implicated in cancer cachexia with regard to BAT activation has been zinc-alphaglycoprotein (ZAG), or lipid-mobilizing factor, which was isolated from the urine of cachectic cancer patients. ${ }^{4}$ Its activity in subcutaneous fat biopsies was recently shown to inversely correlate with weight loss in patients with cancer cachexia. ${ }^{42}$ In animal studies, ZAG purified from the murine adenocarcinoma MAC-16 induced profound cachexia by lipolysis, but not muscle breakdown. ${ }^{43}$ Russell et al. ${ }^{38}$ showed a dose-dependent increase in gross body weight loss and BAT UCP1 protein expression with increasing doses of i.p. administered ZAG. This was accompanied by an increase in BAT oxygen consumption indicating thermogenesis, although its effect on overall energy expenditure was not reported. Presumably, according to these authors, increased levels of plasma fatty acids as a result of ZAG induced lipolysis contributed to an increase im BAT UCP1 and thermogenesis. Interestingly, TNF- $\alpha$ but not ZAG has also been found to up-regulate other UCP subtypes, i.e. UCP2 that is found in low levels in many tissues, and UCP3 found in BAT and skeletal muscle. ${ }^{44,45}$ One should, therefore, also consider the possibility of cytokine driven heat production in other tissues.

Up to now, not many studies have explored the functional response of BAT activity in response to cold in this context. Edstrom et al. ${ }^{46}$ examined cold-induced thermogenesis in cachectic tumor-bearing

Table 1. Rodent studies on cancer cachexia and brown adipose tissue activity, studying the effect of tumour implantation.

\begin{tabular}{|c|c|c|c|c|}
\hline Study & Cancer group & Control group & $\begin{array}{l}\text { Cachexia induction } \\
\text { (vs control group) }\end{array}$ & $\begin{array}{l}\text { BAT activition } \\
\text { (parameter) }^{*}\end{array}$ \\
\hline Bing 27 & $\begin{array}{l}\text { MAC- } 16 \text { adeno-sarcoma from cachectic } \\
\text { animals in NMRI mice, } 18 \text { days }\end{array}$ & Pair fed animals & $\begin{array}{l}++: \mathrm{P}<0.01 \\
(\mathrm{BW}-20 \% \text { vs }-4 \%)\end{array}$ & $++: \mathrm{P}<0.01$ (BAT UCP1 mRNA) \\
\hline Bing 28 & $\begin{array}{l}\text { MAC-16 adeno-sarcoma from cachectic } \\
\text { animals in CD-1mice, } 16 \text { days }\end{array}$ & Sham operated animals & $+: \mathrm{P}=$ n.s. (BW $-19 \%$ of controls) & $\begin{array}{l}++: \mathrm{P}<0.001 \text { (BAT ZAG mRNA } \\
\text { and protein) }\end{array}$ \\
\hline Oudart ${ }^{31}$ & Yoshida sarcoma in Wistar rats, 10 days & $\begin{array}{l}\text { Pair fed, sham operated } \\
\text { animals }\end{array}$ & $\begin{array}{l}\text { - } \mathrm{P}=\text { n.s.d. (carcass mass } 256.5 \\
+/-4.5 \text { g. vs } 262.6+/-5.1 \text { g.) }\end{array}$ & $\begin{array}{l}++\mathrm{P}<0.01 \text { (mitochondrial GDP } \\
\text { binding) }\end{array}$ \\
\hline Lopez-Soriano ${ }^{29}$ & $\begin{array}{l}\text { Yoshida AH-130 hepatoma cells in } \\
\text { Wistar rats, } 7 \text { days }\end{array}$ & $\begin{array}{l}\text { Pair fed, } \mathrm{NaCl} \text { sham } \\
\text { injected animals }\end{array}$ & $\begin{array}{l}++\mathrm{P}<0.01 \text { (carcass mass } 173.8 \\
+/-4.2 \text { g. vs } 191.0+/-3.0 \text { g.) }\end{array}$ & $\begin{array}{l}\text { - } \mathrm{P}=\text { n.s.d. (BAT LPL / BAT mass } \\
\text { in g) }\end{array}$ \\
\hline Lopez-Soriano $0^{30}$ & $\begin{array}{l}\text { Yoshida AH-130 hepatoma cells in } \\
\text { Wistar rats, } 11 \text { days }\end{array}$ & $\begin{array}{l}\mathrm{NaCl} \text { sham injected } \\
\text { animals }\end{array}$ & $++\mathrm{P}<0.001(\mathrm{BW}-30 \%$ vs $+30 \%)$ & $++\mathrm{P}<0.001$ (BAT LPL) \\
\hline Seelaender ${ }^{32}$ & $\begin{array}{l}\text { Walker } 256 \text { carcinosarcoma cells in } \\
\text { Wistar rats, } 14 \text { days }\end{array}$ & $\begin{array}{l}\mathrm{NaCl} \text { sham injected } \\
\text { animals }\end{array}$ & $+\mathrm{P}=$ n.s. $(\mathrm{BW}-13 \%$ vs $+32 \%)$ & + P=n.s. (BAT LPL/ BAT fat \%) \\
\hline Roe $^{33}$ & $\begin{array}{l}\text { T-cell leukemia cells in Piebald } \\
\text { Variegated rats, } 17 \text { days }\end{array}$ & $\begin{array}{l}\text { Pair fed, } \mathrm{NaCl} \text { sham } \\
\text { injected animals }\end{array}$ & $++\mathrm{P}<0.01(\mathrm{BW}-14 \%$ vs $+18 \%)$ & $\begin{array}{l}+\mathrm{P}<0.05 \text { (mitochondrial } \\
\text { GDP binding) }\end{array}$ \\
\hline Brooks ${ }^{12}$ & $\begin{array}{l}\text { Human hypernephroma in } \\
\text { immunosupressed CBACa mice, } 13 \text { days }\end{array}$ & Sham operated animals & $-\mathrm{P}=$ n.s.d. $(\mathrm{BW}-10 \%$ vs $-5 \%)$ & $\begin{array}{l}+\mathrm{P}<0.05 \text { (mitochondrial GDP } \\
\text { binding) }\end{array}$ \\
\hline
\end{tabular}

BAT, brown adipose tissue; UCP1, uncoupling protein 1; BW, body weight; GDP, guanosine diphosphate; ZAG, zinc- $\alpha 2$-glycoprotein; LPL, lipo-proteine lipase; n.s., not specified; n.s.d., not significant.

${ }^{*}$ P values represent the strength of the difference in mean + -- standard deviation or standard error of mean between the intervention group (cancer, cachexia) and the methodologically best available control group (pair fed rather than freely fed, carcass weight rather than body weight) and BAT activity parameter (UCP1, functional test rather than BAT, fat or protein weight). 
mice. Exposure of cold in tumor-bearing mice produced a significantly elevated BAT thermogenic response, although there was no significant difference in carcass weight between animals kept at a temperature of $5^{\circ} \mathrm{C}$ compared to those kept at $25^{\circ} \mathrm{C}$. In this study, neither $\beta$-blockade nor BAT tissue extirpation was shown to impact on body composition. Therefore, these authors concluded that full-blown BAT proliferation and activation was unlikely in cancer cachexia. However, these experiments were not pair-fed controlled because food restriction at $5^{\circ} \mathrm{C}$ resulted in $100 \%$ mortality. Animals kept at $5^{\circ} \mathrm{C}$ had double the food intake of those kept at $25^{\circ} \mathrm{C}$. Recently, Tsoli et al., ${ }^{47}$ found increased BAT activity in C26-induced cachectic mice, as judged by BAT UCP1 protein. This persisted when the animals were acclimatized to $28^{\circ} \mathrm{C}$, despite a dramatically reduced food intake. According to these authors, this confirmed the existence of an inappropriate activation of BAT, representing a maladaptive response to nutrient deprivation in cancer cachexia. Furthermore, ${ }^{18}$ F-FDG PET imaging showed similar kinetics in these cachectic C26 mice as compared to freely-fed, non-tumor bearing animals despite the fact that uptake of ${ }^{18} \mathrm{~F}-\mathrm{FDG}$ is normally reduced in fasting mice, ${ }^{48}$ supporting the concept of an increase in metabolic BAT activity in cancer cachexia.

In summary, Tables 1 and 2 show that most animal studies indicate some degree of BAT activition in cancer cachexia. However, these data do not establish the quantitative impact on the amount of hypermetabolism that is relevant to the development of cachexia. The human and animal studies were retrieved from a systematic literature search of relevant medical databases (Medline, Embase, Cochrane Library) using the key words brown adipose tissue, cancer and cachexia (Supplementary Figure S1).

\section{Human studies on cancer and brown adipose tissue function}

Hibernoma, a rare soft tissue benign tumor composed of brown fat cells, has been associated with massive weight loss as a primary symptom, ${ }^{49}$ suggesting the potential of BAT to significantly contribute to body weight loss in cachexia in humans. Abundant BAT hyperactivity can also be seen on ${ }^{18}$ F-FDG PET scanning in cases of pheochromocytoma as a result of chronic stimulation of the sympathetic nervous system by high levels of circulating catecholamines, such as epinephrine and norepinephrine. ${ }^{50}$ In one case, after removing the pheochromocytoma, and thus the excess of norepinephrine, the intense uptake of ${ }^{18} \mathrm{~F}$ FDG in BAT was no longer seen, ${ }^{51}$ presumably reflecting an involution of BAT. However, such extreme levels of circulating catecholamines in pheochromocytoma are not representative of other cancer types.

In retrospective studies of mixed cancer populations referred for routine ${ }^{18}$ F-FDG PET scanning, single scan observations have shown a prevalence of $5-10 \%$ of BAT positivity in a general oncology patient group ${ }^{52}$ (Figure 2) Rousseau analyzed serial PET-CT scans performed during neo-adjuvant breast cancer chemotherapy in 33 patients. ${ }^{53} \mathrm{~A}$ total of $82 \%$ of patients showed BAT activity on at least one occasion. However, positive PET-CT scans were randomly distributed between patients and time points which, according to the authors, suggested an association of an increased chance of a sufficiently cold environment activating BAT with an increasing number of scans, rather than any correlation to cancer progression or response. Three retrospective studies ${ }^{18,54,55}$ addressed a possible relationship of BAT ${ }^{18} \mathrm{~F}-\mathrm{FDG}$ activity

Table 2. Rodent studies on cancer cachexia and brown adipose tissue activity, studying the effect of tumour mediators.

\begin{tabular}{|c|c|c|c|c|}
\hline Study & Cachexia group & Control group & $\begin{array}{l}\text { Cachexia induction } \\
\text { (vs control group) }\end{array}$ & $\begin{array}{l}\text { BAT activition } \\
\text { (parameter) }^{*}\end{array}$ \\
\hline Coombes 36 & I.v. TNF- $\alpha$ in Wistar rats, 6 days & $\begin{array}{l}\mathrm{NaCl} \text { sham injected } \\
\text { animals }\end{array}$ & $\begin{array}{l}++\mathrm{P}<0.01 \text { (BW }-10 \% \text { of } \\
\text { controls) }\end{array}$ & $\begin{array}{l}+\mathrm{P}<0.05 \text { (mitochondrial GDP } \\
\text { binding) }\end{array}$ \\
\hline Lopez-Soriano ${ }^{37}$ & $\begin{array}{l}\text { Lewis lung carcinoma cells in } \\
\text { rTNF- } \alpha r 1^{0} \text { Wistar rats, } 11 \text { days }\end{array}$ & $\begin{array}{l}\text { Wild type and non-tumor } \\
\text { bearing animals }\end{array}$ & $\begin{array}{l}++\mathrm{P}<0.01 \text { (carcass weight } \\
\text { loss up to } \\
\text { - } 26 \% \text { in wild type } v s \\
-18 \% \text { in TNF- } \alpha 1^{0} \text { ) }\end{array}$ & $\begin{array}{l}+\mathrm{P}<0.05 \text { us non-tumour (BAT } \\
\text { LPL activity) }\end{array}$ \\
\hline Arruda $a^{35}$ & ICV TNF- $\alpha$ in Wistar rats, 4 days & $\begin{array}{l}\text { Pair fed, sham injected } \\
\text { animals }\end{array}$ & $\begin{array}{l}+\mathrm{P}<0.05 \text { (final BM } 241.02+/- \\
5.70 \mathrm{~g} \text { vs } 270.06+/-7.23 \mathrm{~g} \text { ) }\end{array}$ & $\begin{array}{l}+\mathrm{P}<0.05 \text { (BAT UCP1 mRNA and } \\
\text { protein) }\end{array}$ \\
\hline Russell $^{39}$ & $\begin{array}{l}\text { I.v. LMF from urine of weight losing } \\
\text { pancreatic cancer patients, in NMRI } \\
\text { mice, } 2 \text { days }\end{array}$ & $\begin{array}{l}\text { PBS sham injected } \\
\text { animals }\end{array}$ & $++\mathrm{P}=$ n.s. $(\mathrm{BW}-42 \%)$ & $\begin{array}{l}++\mathrm{P}<0.001 \text { (BAT utilization of } \\
{ }^{3} \mathrm{H}-2 \text {-deoxyglucose (2DG) }\end{array}$ \\
\hline Bing 40 & $\begin{array}{l}\text { I.v. LMF from the urine of cachectic } \\
\text { cancer patients ( }>10 \% \text { body weight } \\
\text { loss), in NMRI mice, } 3 \text { days }\end{array}$ & $\begin{array}{l}\text { Weight matched, PBS } \\
\text { sham injected animals }\end{array}$ & $\begin{array}{l}++\mathrm{P}<0.01(\mathrm{BW}-2.24 \mathrm{~g} v s+ \\
0.06 \mathrm{~g} \text {.) }\end{array}$ & $++\mathrm{P}<0.01$ (BAT UCP1mRNA) \\
\hline Russell $^{38}$ & I.p. ZAG in NMRI and MF1 mice, 4 days & $\begin{array}{l}\text { PBS and heat-inactivated } \\
\text { ZAG sham injected } \\
\text { animals }\end{array}$ & $\begin{array}{l}++\mathrm{P}<0.001 \text { (BW } \\
-3.8+/-0.5 \mathrm{~g} \text { till } \\
-1.26+/-0.46 \mathrm{~g} \\
\text { vs }-1.2+/-0.3 \mathrm{~g} \text { till } \\
-0.89+/-0.5 \mathrm{~g} \text { dose- } \\
\text { dependent) }\end{array}$ & $\begin{array}{l}++\mathrm{P}<0.001 \text { (dose-dependent) } \\
\text { (BAT UCP1 protein) }\end{array}$ \\
\hline Johnen $^{41}$ & $\begin{array}{l}\text { I.p. MIC-1 in BALB/c nude mice after } \\
\text { s.c. MIC-1 transfected } 5-7 \times 10^{6} \text { DU145 } \\
\text { prostate carcinoma cells, n.s. }\end{array}$ & $\begin{array}{l}\text { PBS sham and empty } \\
\text { plasmid vector injected } \\
\text { animals }\end{array}$ & $\begin{array}{l}++\mathrm{P}<0.001(\mathrm{BW} \\
-5.3 \mathrm{~g} v s-1.1 \mathrm{~g})\end{array}$ & $--\mathrm{P}<0.001$ (BAT weight) \\
\hline
\end{tabular}


with cancer (Table 3). However, none of these observed a significantly higher incidence of BAT activity in active and/or ${ }^{18}$ F-FDG PET-positive cancer patients. Lee et al. ${ }^{55}$ found BAT activity in $50 \%$ of the scans in patients with evidence of active malignancy compared with $44 \%$ of scans in which there was no ${ }^{18} \mathrm{~F}$-FDG PET-CT evidence of active disease. Other studies ${ }^{18,56}$ have applied a univariate and multivariate analysis on patients with BAT activity and found outdoor temperature, age, sex, BMI and diabetes to be significant variables, but not active cancer $^{56}$ or indication for PET scanning (cancer/no cancer). ${ }^{18}$ The study of van Marken Lichtenbelt et al. ${ }^{17}$ showed a BAT prevalence of as high as $96 \%$ in healthy, young volunteers after a standardized protocol of cold exposure, suggesting that almost all adults possess active or at least potentially active BAT, depending on the degree of BAT stimulation at that moment. The prevalence of BAT activity in cancer patients may thus be considerably higher than that observed so far because these non-controlled studies do not indicate the degree of BAT stimulation represented by the scan at that moment. Routine preparation for ${ }^{18} \mathrm{~F}$-FDG PET scanning in oncology is aimed at reducing BAT uptake by keeping patients warm and sober to avoid false positive findings for a tumor. The sharp discrepancy between the reported 5-10\% in the general population and $96 \%$ in stimulated conditions has led some to conclude that quantitative and qualitative data from retrospective studies must not be considered as indications of the true prevalence of BAT and its physiological control. ${ }^{25}$ Careful consideration of factors co-acting on BAT recruitment and activity, such as diet, cold exposure, physical activity, insulin levels and BMI makes this type of metabolic study challenging, especially for patients.

Virtanen and colleagues ${ }^{16}$ estimated that, by calculating the metabolic rate of glucose uptake (rGU) from dynamic scanning and pharmacokinetic modelling, constant activation of the supraclavicular BAT deposit by moderate cold could burn energy levels equivalent to approximately $4.1 \mathrm{~kg}$ of adipose tissue in one year in healthy subjects. It is unclear how this can relate to the situation in cancer cachexia patients. This amount may be considered an overestimation when comparing the intensity of BAT activity after cold with that in the occasional cancer patient (Figure 2) and considering the fact that most of the patients are thermoneutral, i.e. an environmental temperature at which heat production is not stimulated, which is during most of the day. However, it may be an underestimation if one considers a much larger area of BAT tissue that is activated, not only the supraclavicular deposit, and if brite fat thermogenesis is to be taken into account. These issues need further investigation and require more refined quantitative methods for the ${ }^{18}$ F-FDG-PET-CT scanner to include dif- fuse nests of brite fat that may falsely appear as areas of low activity as a result of the limited spatial resolution of the PET scanner.

Two previous studies examined fat tissue in cancer patients. Bianchi et al. ${ }^{57}$ assessed BAT activity from GDP binding to mitochondria prepared from peroperative samples, and found this to be significantly elevated (by 3 -fold) in children with various malignancies as compared to children undergoing exploratory renal surgery without cancer. In another study by Shellock $e t$ al. ${ }^{58}$ the presence of BAT, as assessed by histological light-microscopic criteria, was determined in peri-adrenal fat tissue acquired during autopsy. In a group of cachectic adult cancer patients BAT was found in $80 \%$ but in only $13 \%$ of patients who died from other illnesses without cancer or cachexia.

In summary, in humans there is no evidence linking BAT activity with cancer cachexia, although studies report a widely variable prevalence of BAT activity depending on the individual metabolic demand at the time of ${ }^{18}$ F-FDG-PET scanning.

\section{Brown adipose tissue energetics}

Humans and rodents share an identical cell composition of the adipose organ, as well as functional BAT characteristics: dense different vascularization, sympathetic innervation with predominately $\beta 3$ adrenoceptors, UCP1 as the characteristic mitochondrial membrane protein in brown adipocytes, dependency on ambient temperature. ${ }^{59}$ In smaller mammals, such as rodents, cold activated BAT thermogenesis has a substantial impact on total energy expenditure. From mice studies, the maximum heat-producing capacity has been established to be $300 \mathrm{~W} / \mathrm{kg} .{ }^{34}$ For the moment, no information is available on the contribution of BAT thermogenesis to whole body energy expenditure in humans, although a recent study using ${ }^{11} \mathrm{C}$-acetate PET-CT provides evidence of metabolic factors contributing to non-shivering thermogenesis. ${ }^{60}$ In mammals, mass-specific energy expenditure (i.e. per unit tissue mass) is negatively related to body size. Taking such allometric relations into account, it can be calculated from the data from rodents that human activated BAT would spend $45 \mathrm{~W} / \mathrm{kg} .{ }^{61}$ Rothwell and Stock estimated 40-50 g BAT in humans; ${ }^{62}$ this would result in 3-5\% of basal metabolic rate (BMR). Using ${ }^{18}$ F-FDG PET-CT scanning, Virtanen ${ }^{16}$ estimated BAT volume to be slightly higher at $63 \mathrm{~g}$, while assuming the contribution of glucose to overall BAT substrate use to be $10 \%{ }^{63}$ This resulted in an estimated heat production of activated BAT of $55 \mathrm{~W} / \mathrm{kg}$, or approximately $4.5 \%$ of BMR. These calculations suggest that BAT activity can have a substantial impact on daily energy expenditure.

In addition, BAT may be differently activated depending upon the physiological stimulus. Orava et al. ${ }^{64}$ showed that BAT is a highly

Table 3. Human studies on cancer cachexia and brown adipose tissue activity, studying the effect of tumour presence.

\begin{tabular}{|c|c|c|c|c|}
\hline Study & Cancer group & Control group & $\begin{array}{l}\text { Cachexia induction } \\
\text { (vs control group) }\end{array}$ & $\begin{array}{l}\text { BAT activition } \\
\text { (parameter) }\end{array}$ \\
\hline Cypess $^{18}$ & $\begin{array}{l}\text { Adults; lymphoma and other cancers } \\
\text { from mixed PET population }(\mathrm{n}=1972)\end{array}$ & No-cancer & n.s. & - P=n.s.d. (BAT ${ }^{18} \mathrm{~F}-\mathrm{FDG}$ activity) \\
\hline Quellet ${ }^{56}$ & $\begin{array}{l}\text { Adults; active cancers from mixed PET } \\
\text { population }(\mathrm{n}=4842)\end{array}$ & No-cancer & n.s. & - $\mathrm{P}=$ n.s.d. (BAT ${ }^{18} \mathrm{~F}-\mathrm{FDG}$ activity) \\
\hline $\operatorname{Lee}^{55}$ & $\begin{array}{l}\text { Adults; active (PET positive) malignancies } \\
\text { from mixed cancer population }(\mathrm{n}=2934)\end{array}$ & Tumor PET negative & n.s. & - $\mathrm{P}=$ n.s.d. (BAT ${ }^{18} \mathrm{~F}-\mathrm{FDG}$ activity) \\
\hline Bianchi $^{57}$ & Pediatric; mixed cancer types $(n=8)$ & $\begin{array}{l}\text { No-cancer (pyelo-plasty) } \\
(\mathrm{n}=9)\end{array}$ & $\begin{array}{l}+\mathrm{P}=\mathrm{n} . \mathrm{s} \text {. (evidence of recent } \\
\text { weight loss) }\end{array}$ & $\begin{array}{l}+\mathrm{P}<0.05 \text { (mitochondrial GDP } \\
\text { binding in perirenal fat) }\end{array}$ \\
\hline Shellock ${ }^{58}$ & $\begin{array}{l}\text { Adults; mixed cancer types ( } \mathrm{n}=25) \text {; } \\
\text { all cachexia; autopsy study }\end{array}$ & $\begin{array}{l}\text { Age-matched, no-cancer, } \\
\text { no-cachexia }(\mathrm{n}=15)\end{array}$ & $\begin{array}{l}+\mathrm{P}=\text { n.s. (cachexia according to } \\
\text { pathologist) }\end{array}$ & $\begin{array}{l}+\mathrm{P}=\text { n.s. (microscopic BAT in } \\
\text { peri-adrenal fat) }\end{array}$ \\
\hline
\end{tabular}


insulin-sensitive tissue. Insulin administration by an euglycemic, hyperinsulinemic clamp technique led to a 5 -fold increase in BAT glucose uptake. This reinforces the view that BAT plays a role in human metabolism and may be of relevance in cancer cachexia in which many of the metabolic abnormalities of type II diabetes mellitus, including glucose intolerance, increased hepatic glucose production and recycling, and insulin resistance have been reported, even prior to the development of severe malnutrition. ${ }^{65}$

\section{Conclusions}

Animal experiments provide some evidence for an association between BAT activation and cancer cachexia. Given the similarities in anatomy and BAT function between rodents and humans, such a relation may also exist in humans. The proliferation of ${ }^{18}$ F-FDG PET-CT scanners in cancer centers supplies researchers with a new tool to study BAT and human energy balance. However, current retrospective observations in cancer patients do not support a clinically relevant association between BAT and cancer cachexia. Still, the large discrepancy between retrospective and prospective data shows that methodology is critical in these types of metabolic studies. Therefore, further prospective and well controlled studies are warranted to provide more solid evidence in this field. In animal studies, cancer cachexia models should resemble the human situation as close as possible in terms of end points, degree of anorexia, muscle and fat loss, tumor to body weight, metabolic abnormalities, hormonal changes and cytokine profile. ${ }^{66}$ In human studies, ${ }^{18}$ F-FDG PET-CT scanning seems the preferred examination mode to establish patterns of BAT activation and recruitment during pre-cachexia development as compared to age and gender matched normal adults. Direct correlation to measurements of energy expenditure, body temperature and weight loss is essential. Scans should be performed in stimulated circumstances such as at cold temperatures, in order to evaluate the full amount of active BAT present. Co-factors that act on BAT should be controlled or simultaneously measured: age, gender, temperature conditions, season, BMI, physical activity, prior diet, medication ( $\beta$-adrenoceptor agents), cytokines (CRP, TNF- $\alpha$, IL-6), hormonal profile (thyroid hormones, insulin), body composition changes (fat mass, lean mass), presence of metabolic pathologies such as obesity, diabetes. In animal and human studies, UCP1 protein is the preferred parameter in brown and brite fat tissue biopsies to assess specific thermogenic activity. In intervention studies, ${ }^{18}$ F-FDG PET-CT can be used to study the effects of a $\beta 3$-adrenoceptor antagonist on BAT activation and cachexia before, during and after initiation of treatment.

\section{References}

1. Fearon K, Strasser F, Anker SD, et al. Definition and classification of cancer cachexia: an international consensus. Lancet Oncol 2011;12:489-95.

2. Wys WDD. Weight loss and nutritional abnormalities in cancer patients: incidence, severity and significance. Calman kc Fk, editor. London: Saunders; 1986.

3. Laviano A, Inui A, Marks DL, et al. Neural control of the anorexiacachexia syndrome. Am J Physiol Endocrinol Metab 2008;295: E1000-8.

4. Tisdale MJ. Mechanisms of cancer cachexia. Physiol Rev 2009;89:381-410.

5. Blum D, Omlin A, Baracos VE, et al. Cancer cachexia: A systematic literature review of items and domains associated with involuntary weight loss in cancer. Crit Rev Oncol Hematol 2011;80:114-44.

6. Cao DX, Wu GH, Zhang B, et al. Resting energy expenditure and body composition in patients with newly detected cancer. Clin Nutr 2010;29:72-7.

7. Bosaeus I, Daneryd P, Svanberg E, Lundholm K. Dietary intake and resting energy expenditure in relation to weight loss in unselected cancer patients. Int J Cancer 2001;93:380-3.

8. Staal-van den Brekel AJ, Schols AM, ten Velde GP, et al. Analysis of the energy balance in lung cancer patients. Cancer Res 1994;54: 6430-3.

9. Staal-van den Brekel AJ, Dentener MA, Schols AM, et al. Increased resting energy expenditure and weight loss are related to a systemic inflammatory response in lung cancer patients. J Clin Oncol 1995;13:2600-5.

10. Hyltander A, Drott C, Korner U, et al. Elevated energy expenditure in cancer patients with solid tumours. Eur J Cancer 1991;27:9-15.

11. Lieffers JR, Mourtzakis M, Hall KD, et al. A viscerally driven cachexia syndrome in patients with advanced colorectal cancer: contributions of organ and tumor mass to whole-body energy demands. Am J Clin Nutr 2009;89:1173-9.

12. Brooks SL, Neville AM, Rothwell NJ, et al. Sympathetic activation of brown-adipose-tissue thermogenesis in cachexia. Biosci Rep 1981;1:509-17.

13. Hany TF, Gharehpapagh E, Kamel EM, et al. Brown adipose tissue: a factor to consider in symmetrical tracer uptake in the neck and upper chest region. Eur J Nucl Med Mol Imaging 2002;29:1393-8.

14. Nedergaard J, Bengtsson T, Cannon B. Unexpected evidence for active brown adipose tissue in adult humans. Am J Physiol Endocrinol Metab 2007;293:E444-52.

15. Saito M, Okamatsu-Ogura Y, Matsushita M, et al. High incidence of metabolically active brown adipose tissue in healthy adult humans: effects of cold exposure and adiposity. Diabetes 2009;58:1526-31.

16. Virtanen KA, Lidell ME, Orava J, et al. Functional brown adipose tissue in healthy adults. N Engl J Med 2009;360:1518-25.

17. van Marken Lichtenbelt WD, Vanhommerig JW, Smulders NM, et al. Cold-activated brown adipose tissue in healthy men. $\mathrm{N}$ Engl J Med 2009;360:1500-8.

18. Cypess AM, Lehman S, Williams G, et al. Identification and importance of brown adipose tissue in adult humans. N Engl J Med 2009; 360:1509-17.

19. Baba S, Engles JM, Huso DL, et al. Comparison of uptake of multiple clinical radiotracers into brown adipose tissue under cold-stimulated and nonstimulated conditions. J Nucl Med 2007;48:1715-23.

20. Yoneshiro T, Aita S, Matsushita M, et al. Brown adipose tissue, whole-body energy expenditure, and thermogenesis in healthy adult men. Obesity (Silver Spring) 2011;19:13-6.

21. Timmons JA, Wennmalm K, Larsson 0 , et al. Myogenic gene expression signature establishes that brown and white adipocytes originate from distinct cell lineages. Proc Natl Acad Sci U S A 2007; 104:4401-6.

22. Cinti S. Between brown and white: novel aspects of adipocyte differentiation. Ann Med 2011;43:104-15.

23. Cinti S. Reversible physiological transdifferentiation in the adipose organ. Proc Nutr Soc 2009;68:340-9.

24. Ravussin E, Galgani JE. The implication of brown adipose tissue for humans. Annu Rev Nutr 2011;31:33-47.

25. Nedergaard J, Bengtsson T, Cannon B. Three years with adult human brown adipose tissue. Ann N Y Acad Sci 2010;1212:E20-36.

26. Tews D, Wabitsch M. Renaissance of brown adipose tissue. Horm Res Paediatr 2011;75:231-9.

27. Bing $\mathrm{C}$, Brown $\mathrm{M}$, King $\mathrm{P}$, et al. Increased gene expression of brown fat uncoupling protein (UCP)1 and skeletal muscle UCP2 and UCP3 in MAC16-induced cancer cachexia. Cancer Res 2000;60: 2405-10. 
28. Bing C, Bao Y, Jenkins J, et al. Zinc-alpha2-glycoprotein, a lipid mobilizing factor, is expressed in adipocytes and is up-regulated in mice with cancer cachexia. Proc Natl Acad Sci USA 2004;101:2500-5.

29. Lopez-Soriano J, Argiles JM, Lopez-Soriano FJ. Lipid metabolism in rats bearing the Yoshida $\mathrm{AH}-130$ ascites hepatoma. Mol Cell Biochem 1996;165:17-23.

30. Lopez-Soriano J, Argiles JM, Lopez-Soriano FJ. Sequential changes in lipoprotein lipase activity and lipaemia induced by the Yoshida AH-130 ascites hepatoma in rats. Cancer Lett 1997;116:159-65.

31. Oudart H, Calgari C, Andriamampandry M, Le Maho Y, Malan A. Stimulation of brown adipose tissue activity in tumor-bearing rats. Can J Physiol Pharmacol 1995;73:1625-31.

32. Seelaender MC, Nascimento CM, Curi R, Williams JF. Studies on the lipid metabolism of Walker 256 tumour-bearing rats during the development of cancer cachexia. Biochem Mol Biol Int 1996;39: 1037-47.

33. Roe S, Cooper AL, Morris ID, Rothwell NJ. Mechanisms of cachexia induced by T-cell leukemia in the rat. Metabolism 1996;45:64551.

34. Cannon B, Nedergaard J. Brown adipose tissue: function and physiological significance. Physiol Rev 2004;84:277-359.

35. Arruda AP, Milanski M, Romanatto T, et al. Hypothalamic actions of tumor necrosis factor alpha provide the thermogenic core for the wastage syndrome in cachexia. Endocrinology 2010;151:683-94.

36. Coombes RC, Rothwell NJ, Shah P, Stock MJ. Changes in thermogenesis and brown fat activity in response to tumour necrosis factor in the rat. Biosci Rep 1987;7:791-9.

37. Lopez-Soriano J, Llovera M, Carbo N, et al. Lipid metabolism in tumour-bearing mice: studies with knockout mice for tumour necrosis factor receptor 1 protein. Mol Cell Endocrinol 1997;132:93-9.

38. Russell ST, Zimmerman TP, Domin BA, Tisdale MJ. Induction of lipolysis in vitro and loss of body fat in vivo by zinc-alpha2-glycoprotein. Biochim Biophys Acta 2004;1636:59-68.

39. Russell ST, Tisdale MJ. Effect of a tumour-derived lipid-mobilising factor on glucose and lipid metabolism in vivo. Br J Cancer 2002; 87:580-4.

40. Bing C, Russell ST, Beckett EE, et al. Expression of uncoupling proteins- $1,-2$ and -3 mRNA is induced by an adenocarcinoma-derived lipid-mobilizing factor. Br J Cancer 2002;86:612-8.

41. Johnen H, Lin S, Kuffner T, et al. Tumor-induced anorexia and weight loss are mediated by the TGF-beta superfamily cytokine MIC-1. Nat Med 2007;13:1333-40.

42. Mracek T, Stephens NA, Gao D, et al. Enhanced ZAG production by subcutaneous adipose tissue is linked to weight loss in gastrointestinal cancer patients. Br J Cancer 2011;104:441-7.

43. Tisdale MJ. Zinc-alpha2-glycoprotein in cachexia and obesity. Curr Opin Support Palliat Care 2009;3:288-93.

44. Eckardt K, Schober A, Platzbecker B, et al. The adipokine zincalpha2-glycoprotein activates AMP kinase in human primary skeletal muscle cells. Arch Physiol Biochem 2011;117:88-93.

45. Masaki T, Yoshimatsu H, Chiba S, et al. Tumor necrosis factoralpha regulates in vivo expression of the rat UCP family differentially. Biochim Biophys Acta 1999;1436:585-92.

46. Edstrom S, Kindblom LG, Lindmark L, Lundholm K. Metabolic and morphologic changes in brown adipose tissue from non-growing mice with an isogeneic sarcoma. Evaluation with respect to development of cachexia. Int J Cancer 1986;37:753-60.

47. Tsoli M MM, Painter A, Berghofer P, Gregoire M-C, Katsifis A, Clarke S, Robertson, editor. Activation of BAT in cancer cachexia/anorexia syndrome: a maladaptive response to reduced food intake driven by tumour-derived IL-6. Pre-congress meeting on brown adipose tissue and human obesity; 2010 July, 10-11; Stockholm.

48. Fueger BJ, Czernin J, Hildebrandt I, et al. Impact of animal handling on the results of ${ }^{18}$ F-FDG PET studies in mice. J Nucl Med 2006;47:999-1006.

49. Essadel A, Bensaid Alaoui S, Mssrouri R, et al. [Hibernoma: a rare case of massive weight loss]. Ann Chir 2002;127:215-7.

50. Wang $Q$, Zhang M, Ning G, et al. Brown adipose tissue in humans is activated by elevated plasma catecholamines levels and is inversely related to central obesity. PloS One 2011;6:e21006.

51. Yamaga LY, Thom AF, Wagner J, et al. The effect of catecholamines on the glucose uptake in brown adipose tissue demonstrated by (18)F-FDG PET/CT in a patient with adrenal pheochromocytoma. Eur J Nucl Med Mol Imaging 2008;35:446-7.

52. Cohade C. Altered biodistribution on FDG-PET with emphasis on brown fat and insulin effect. Semin Nucl Med 2010;40:283-93.

53. Rousseau C, Bourbouloux E, Campion L, et al. Brown fat in breast cancer patients: analysis of serial (18)F-FDG PET/CT scans. Eur J Nucl Med Mol Imaging 2006;33:785-91.

54. Ouellet V, Routhier-Labadie A, Bellemare W, et al. Outdoor temperature, age, sex, body mass index, and diabetic status determine the prevalence, mass, and glucose-uptake activity of ${ }^{18}$ F-FDG-detected BAT in humans. J Clin Endocrinol Metab 2011;96:192-9.

55. Lee P, Greenfield JR, Ho KK, Fulham MJ. A critical appraisal of the prevalence and metabolic significance of brown adipose tissue in adult humans. Am J Physiol Endocrinol Metab 2010;299:E601-6.

56. Ouellet V, Routhier-Labadie A, Bellemare W, et al. Outdoor temperature, age, sex, body mass index, and diabetic status determine the prevalence, mass, and glucose-uptake activity of ${ }^{18}$ F-FDG-detected BAT in humans. J Clin Endocrinol Metab 2011;96:192-9.

57. Bianchi A, Bruce J, Cooper AL, et al. Increased brown adipose tissue activity in children with malignant disease. Horm Metab Res 1989;21:640-1.

58. Shellock FG, Riedinger MS, Fishbein MC. Brown adipose tissue in cancer patients: possible cause of cancer-induced cachexia. J Cancer Res Clin Oncol 1986;111:82-5.

59. Zingaretti MC, Crosta F, Vitali A, et al. The presence of UCP1 demonstrates that metabolically active adipose tissue in the neck of adult humans truly represents brown adipose tissue. FASEB J 2009;23:3113-20.

60. Ouellet V, Labbe SM, Blondin DP, et al. Brown adipose tissue oxidative metabolism contributes to energy expenditure during acute cold exposure in humans. J Clin Invest 2012;122:545-52.

61. van Marken Lichtenbelt WD, Schrauwen P. Implications of nonshivering thermogenesis for energy balance regulation in humans. Am J Physiol Regul Integr Comp Physiol 2011;301:R285-96.

62. Rothwell NJ, Stock MJ. A role for brown adipose tissue in dietinduced thermogenesis. Nature 1979;281:31-5.

63. Ma SW, Foster D0. Uptake of glucose and release of fatty acids and glycerol by rat brown adipose tissue in vivo. Can J Physiol Pharmacol 1986;64:609-14.

64. Orava J, Nuutila P, Lidell ME, et al. Different metabolic responses of human brown adipose tissue to activation by cold and insulin. Cell Metab 2011;14:272-9.

65. Tayek JA. A review of cancer cachexia and abnormal glucose metabolism in humans with cancer. J Am Coll Nutr 1992;11:445-56.

66. Bennani-Baiti N, Walsh D. Animal models of the cancer anorexiacachexia syndrome. Support Care Cancer 2011;19:1451-63. 